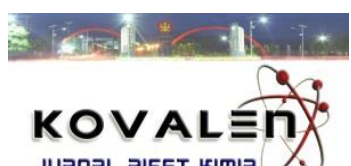

JURTRL RISET KIImIa.

\title{
EKSTRAKSI DAN KARAKTERISASI PEKTIN DARI KULIT BUAH MANGGA HARUMANIS (Mangifera Indica L.) BERDASARKAN VARIASI SUHU DAN WAKTU
}

\section{[Extraction and Characterization of Pectin from Harumanis Mango Peels With Various Temperatures and Times]}

\author{
Nurmila $^{1^{\star}}$, Nurhaeni ${ }^{1}$, Ahmad Ridhay ${ }^{1}$ \\ 1) Jurusan Kimia, Fakultas MIPA, Universitas Tadulako, Palu \\ Jl. Soekarno Hatta Km.9, Kampus Bumi Tadulako Tondo Palu, Telp. 0451- 422611 \\ *)Coresponding author: Nhurmilaa@gmail.com (+6287761392070)
}

Diterima 7 Desember 2018, Disetujui 16 Februari 2019

\begin{abstract}
Research about extraction and characterization of pectin from harumanis mango peel (Mangifera indica $L$.) in various of temperature and time has been done. The objective of this research is to determine the extraction temperature and time in producing pectin with the highest yield and pectin characteristics. The research method was a Completely Randomized Design (CRD) with 5 levels of extraction temperature (60-65, 70-75, 80-85, 90-95 and 100-105 $\left.{ }^{\circ} \mathrm{C}\right)$, respectively and 6 levels of extraction time $(60,90,120,150,180$, and 210 minutes), respectively, and all were done triplicate. The result showed that the optimum extraction temperature was $90-95^{\circ} \mathrm{C}$ with yield of $40.19 \%$ and extraction time was 150 minutes with yield of $49.13 \%$. The obtained pectin has following characters, water content of $8.2 \%$, methoxyl content of $9.569 \%$, galacturonate content of $74.155 \%$. The result of FTIR spectroscopy indicates the existence of fuctional groups corresponding to the structure of pectin.
\end{abstract}

Keywords : extraction, characterization, pectin, harumanis mango pell.

\begin{abstract}
ABSTRAK
Telah dilakukan penelitian ekstraksi dan karakterisasi pektin dari kulit buah mangga harumanis (Mangifera indica L.) berdasarkan variasi suhu dan waktu. Tujuan penelitian adalah untuk mengetahui suhu ekstraksi dan waktu ekstraksi terbaik untuk menghasilkan ekstrak pektin dengan rendemen tertinggi dan karakteristik pektin. Penelitian ini menggunakan Rancangan Acak Lengkap (RAL) yang terdiri atas 2 faktor yaitu suhu ekstraksi terdiri atas 5 taraf (60-65, 70-75, 80-85, 90-95, dan 100-105 $\left.{ }^{\circ} \mathrm{C}\right)$ dan waktu ekstraksi terdiri atas 6 taraf $(60,90,120,150,180$, dan 210 menit) yang masingmasing dilakukan sebanyak 3 kali pengulangan. Hasil penelitian menunjukkan bahwa suhu ekstraksi terbaik diperoleh pada $90-95^{\circ} \mathrm{C}$ dengan rendemen pektin $40,19 \%$ dan waktu ekstraksi terbaik diperoleh pada 150 menit dengan rendemen pektin 49,13\%. Hasil karakteristik pektin yang diperoleh antara lain yaitu kadar air 8,2\%, kadar metoksil 9,57\% kadar galakturonat 74,16\%. Hasil identifikasi spektroskopi FTIR dengan masing-masing serapan pada gelombang tertentu menunjukkan adanya gugus fungsi yang sesuai dengan struktur pektin.
\end{abstract}

Kata kunci : ekstraksi, karakterisasi, pektin, kulit manga harumanis. 


\section{LATAR BELAKANG}

Tanaman mangga merupakan tanaman pengahasil buah yang banyak terdapat di Sulawesi Tengah. Konsumsi buah manga umumnya langsung dalam keadaan segar atau diolah dalam bentuk jus, manisan, irisan buah dalam kaleng, dan lain-lain. Mangga juga sering dicampurkan dalam olahan sambal atau dalam masakan ikan dan daging. Di lain pihak, kulitnya terbuang begitu saja sebagai limbah. Limbah kulit mangga tersebut sangat potensial dimanfaatkan sebagai sumber pektin (Sutono, 2008).

Pektin dari buah umumnya terdapat pada bagian kulit buah O'Neil MA et al. (2014), seperti pektin dari kulit buah kluwih (Febriyanti et al, 2018) dan kulit buah nangka (Injilaudin et al., 2015). Ketersedian bahan pangan yang lain masih memungkinkan untuk dijadikan pektin. Hal ini yang menjadi alasan bagi para peneliti untuk menemukan sumber pektin yang lain, salah satunya pada kulit buah mangga. Mengingat kebutuhan pektin dibidang industri dan farmasi, komsumsi pektin dari tahun ketahun meningkat (Budiyanto dan Yulianingsih, 2008).

Pektin termasuk biopolimer golongan karbohidrat dapat diekstrak dengan asam encer. Jenis pektin yang mudah diekstraksi dengan asam encer adalah $\propto$-Dgalakturonat yang mengandung metil ester (Willats et al., 2006). Kadar senyawa pektin dalam buah dipengaruhi tingkat kematangan, buah mengkal umumnya memiliki kadar pektin yang lebih tingg dan menurun pada saat buah matang penuh dan lewat matang. Tanaman yang berfotosintesis menghasilkan pektin terletak pada bagian antara sel dengan dinding sekunder termasuk xilem dan sel-sel serat dalam jaringan kayu. Salah satu cara untuk mendapatkan pektin, yaitu dengan metode ekstraksi yang dilanjutkan dengan pemisahan pektin dari ekstrak (Ulfia, 2016).

Umumnya ekstraksi pektin dilakukan dengan menggunakan pelarut asam, baik asam mineral maupun asam organik, seperti asam sulfat, asam klorida, asam asetat asam nitrat dan asam sitrat (Fitriani, 2003). Senyawa asam akan memisahkan ion polivalen, mampu menghidrolisis protopektin menjadi molekul yang lebih kecil dan memutus ikatan antara pektinat dengan selusosa serta menghidrolisis gugus metil ester (Kertesz, 1951). Rachmawan et al. (2005) menambahkan bahwa kekuatan asam akan mempengaruhi karakteristik pektin . Asam sitrat merupakan pelarut yang baik dari segi ekonomi dan juga dari sudut pandang lingkungan (Arviani, 2009).

Kondisi ekstraksi pektin juga berpengaruh terhadap karaktistik pektin dan sifat fisik pektin tergantung dari karakteristik kimia pektin (Nuh, 2017). Berbagai faktor yang mempengaruhi ekstraksi pektin antara waktu kontak, jenis pelarut, suhu ekstraksi, rasio antara sampel dan pelarut serta jenis pelarut yang digunakan (Prasetyowati dan Pesantri, 2009). 
Makin tinggi suhu ekstraksi makin singkat waktu yang dibutuhkan untuk mendapatkan hasil yang maksimum (Akmalludin, 2009). Hasil penelitian Nuh, M (2017) menyatakan suhu ekstraksi terbaik pada kulit pisang kepok dalam pelarut asam sitrat yaitu $100^{\circ} \mathrm{C}$, rendemen pektin diperoleh $31,71 \%$. Madjaga et al (2017) menyatakan suhu ekstraksi terbaik dari kulit buah sukun dalam pelarut asam sitrat $7 \%$, yaitu $90-95^{\circ} \mathrm{C}$ dengan rendemen pektin $39,585 \%$.

Hasil penelitian Nurviani et al. (2014) menyatakan waktu terbaik ekstraksi kulit buah papaya semangka dalam pelarut asam sitrat $7 \%$ yaitu selama 120 menit, rendemen pektin yang diperoleh yaitu 12,70\%. Margani et al. (2012), menyatakan waktu terbaik ekstraksi kulit buah nangka 150 menit, rendemen pektin yang diperoleh 10,21\% dengan hasil pelarut terbaik menggunakan asam sitrat.

Berdasarkan uraian di atas maka dilakukan penelitian tentang ekstraksi dan karakterisasi pektin dari kulit buah mangga harumanis (Mangifera indica L).

\section{METODE PENELITIAN}

\section{Bahan dan Peralatan}

Bahan yang digunakan dalam penelitian ini adalah kulit buah mangga harum manis (Mangivera indica L.), asam sitrat $7 \%$, etanol $96 \%, \mathrm{NaOH} 0,1 \mathrm{~N}, \mathrm{HCl}$ $0,1 \mathrm{~N}$, aquades, indikator fenoftalien, kertas indikator universal, kertas saring dan aluminium foil.
Alat yang digunakan dalam penelitian ini adalah pisau, blender, ayakan 60 mesh, batang pengaduk, neraca analitik, hot plate, oven analitik, corong buchner, cawan petri, statif dan klem, serta stopwatch.

\section{Prosedur Penelitian}

\section{Persiapan Bahan}

Kulit buah mangga dicuci bersih untuk menghilangkan kotoran yang menempel kemudian dipotong-potong dan di jemur di bawah sinar matahari hingga kering. Kulit buah yang telah kering dihancurkan dengan blender kemudian diayak dengan menggunakan ayakan berukuran 60 mesh. Penepungan kulit buah mangga dilakukan untuk memperoleh partikel yang berukuran kecil sehingga dapat memudahkan proses ekstraksi pektin.

\section{Ekstraksi Pektin}

\section{Variasi Suhu Ekstraksi (Madjaga et al., 2017)}

Tepung kulit buah mangga ditimbang sebanyak 10 gram, ditambahkan $500 \mathrm{~mL}$ asam sitrat 7\%. Ekstraksi pektin dilakukan dengan pemanasan pada suhu $60-65^{\circ} \mathrm{C}$, $70-75^{\circ} \mathrm{C}, \quad 80-85^{\circ} \mathrm{C}, \quad 90-95^{\circ} \mathrm{C}$ dan $100-$ $105^{\circ} \mathrm{C}$, selama 120 menit. Hasil ekstraksi disaring dengan kain saring dalam keadaan panas. Filtrat hasil penyaringan didinginkan dan diendapkan dengan menambahkan etanol $96 \%$ dengan perbandingan volume 1:1,5 sambil diadukaduk sehingga terbentuk endapan, dan diendapkan selama 24 jam. Endapan 
dipisahkan dari larutannya dengan cara disaring menggunakan kertas saring. Dilakukan pencucian endapan dengan menggunakan etanol secara berulangulang, dikeringkan dalam oven pada suhu $50^{\circ} \mathrm{C}$ selama 24 jam.

\section{Variasi Waktu Ekstraksi (Madjaga et al., 2017)}

Tepung kulit buah mangga ditimbang sebanyak 10 gram, ditambahkan 500 mL asam sitrat 7\%. Ekstraksi pektin dilakukan dengan pemanasan pada suhu terbaik, dengan waktu ekstraksi 60 menit, 90 menit, 120 menit, 150 menit, 180 menit dan 210 menit. Hasil ekstraksi disaring dengan kain saring dalam keadaan panas. Filtrat hasil penyaringan didinginkan dan diendapkan dengan menambahkan etanol $96 \%$ dengan perbandingan volume 1:1,5 sambil diaduk-aduk sehingga terbentuk endapan, dan diendapkan selama 24 jam.

Endapan dipisahkan dari larutannya dengan cara disaring menggunakan kertas saring. Dilakukan pencucian endapan dengan menggunakan etanol secara berulang-ulang, dikeringkan dalam oven pada suhu $50^{\circ} \mathrm{C}$ selama 24 jam.

\section{Penentuan Kadar Air (Prasetyowati dan Pesantri, 2009)}

Ditimbang 0,5 gram sampel dalam cawan porselin, dikeringkan dalam oven pada suhu $80^{\circ} \mathrm{C}-100^{\circ} \mathrm{C}$ selama 30 menit. Didinginkan dalam desikator dan ditimbang. Dipanaskan lagi dalam oven selama 30 menit, didinginkan dalam desikator lalu ditentukan lagi beratnya.
Proses ini dilakukan sampai beratnya konstan dan setelah penimbangan berturut-turut kurang dari 0,2 miligram.

\section{Analisis Kadar Metoksil (Akhmalludin dan Kurniawan, 2009)}

Pektin kering yang diperoleh dianalisis kandungan metoksil dengan galakturonatnya. Dilakukan dengan cara melarutkan 0,5 gram pektin kering dengan $100 \mathrm{ml}$ aquades. Ditambahkan 6 tetes fenoftalin, dititrasi dengan $0,1 \mathrm{~N} \mathrm{NaOH}$. Titik ekivalen ditandai dengan perubahan warna dari putih kecoklatan sampai kemerah muda. Volume $\mathrm{NaOH}$ yang dibutuhkan dicatat $\left(\mathrm{V}_{1}\right)$. Ditambahkan 6 tetes larutan $\mathrm{HCL} 0,1 \mathrm{~N}$ dan dikocok, larutan didiamkan selama 15 menit.

\section{Analisis Kadar Galakturonat (Akhmalludin dan Kurniawan, 2009)}

Larutan hasil pendiaman pada penentuan kadar metoksil, dikocok sampai warna merah muda hilang dan ditambah 6 tetes fenoflatin serta dititrasi dengan $\mathrm{NaOH} 0,1 \mathrm{~N}$ sampai timbul warna merah muda.

\section{Analisis Spektrum FTIR}

Ditimbang serbuk kering $\mathrm{KBr}$ sebanyak 0,3 gram. Timbang 0,015 gram pektin. Pektin dan serbuk $\mathrm{KBr}$ dicampurkan dan dikompresi dalam pellet press dengan kompresi hidrolitik berkekuatan 10 torr yang dihubungkan dengan pompa vakum. Pelet campuran $\mathrm{KBr}$ dan sampel diletakkan diantara 2 celah yang dilewati berkas sinar inframerah. Diatur spektrumnya pada 
rentang Panjang gelombang 4000 $400 \mathrm{~cm}^{-1}$, kemudian dianalisis dengan spektrum FT-IR.

\section{HASIL DAN PEMBAHASAN}

\section{Rendemen Pektin Pada Berbagai Suhu Ekstraksi}

Menurut Prasetyowati (2009), suhu pelarut akan mempengaruhi ikatan antar molekul protopektin. Penelitian ini menerapkan 5 variasi suhu yaitu $60-65^{\circ} \mathrm{C}$, $70-75^{\circ} \mathrm{C}, \quad 80-85^{\circ} \mathrm{C}, \quad 90-95^{\circ} \mathrm{C}$ dan $100-$ $105^{\circ} \mathrm{C}$. Hasil yang ditunjukan pada (Gambar 1), diperoleh rendemen pektin pada tiap variasi suhu yaitu $17,59 \%$, 23,74\%, 31,23\%, 40,19\%, 37,63\%. Hasil yang diperoleh menunjukkan bahwa semakin meningkatnya suhu ekstraksi yang digunakan, rendemen pektin yang diperoleh semakin tinggi.

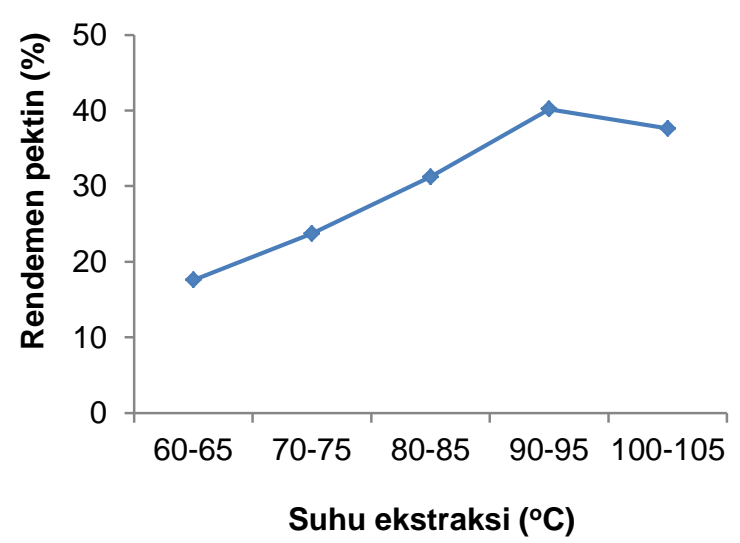

Gambar 1. Pengaruh suhu ekstraksi terhadap rendemen pektin

Menurut Nuh (2017) semakin tinggi suhu ekstraksi maka protopektin (senyawa pektin yang tidak larut dalam air) akan semakin banyak terhidrolisis menjadi pektin yang larut dalam air sehingga rendemen yang dihasilkan semakin besar. Namun pada suhu ekstraksi $100-105^{\circ} \mathrm{C}$, rendemen pektin yang diperoleh menurun, hal ini disebabkan suhu hidrolisis terlalu tinggi. Suhu ekstraksi pektin umumnya antara $60-100^{\circ} \mathrm{C}$ (Towle dan Christensen, 1997).

Hasil analisis uji statistik pada tabel sidik ragam Anova, menggunakan taraf kepercayaan $95 \%(\alpha=0,05)$ dengan nilai signifikan 0,00 ( $\mathrm{p}$ value $)<\alpha$ dengan kata lain terdapat pengaruh suhu ekstraksi terhadap rendemen pektin yang dihasilkan, oleh karena itu dapat dilakukan analisis lanjut dengan uji Duncan untuk menentukan suhu ekstrasi terbaik pada kulit buah mangga.

Hasil uji lanjut Duncan dengan taraf kepercayaan 95\% $(\alpha=0,05)$ menunjukkan terbentuknya 5 kolom yang dihasilkan tiap kelompok pada kolom yang berbeda. Berdasarkan data tersebut dapat disimpulkan suhu ekstraksi $60^{\circ} \mathrm{C}-65^{\circ} \mathrm{C}$, $70^{\circ} \mathrm{C}-75^{\circ} \mathrm{C}, \quad 80^{\circ} \mathrm{C}-85^{\circ} \mathrm{C}, \quad 100^{\circ} \mathrm{C}-105^{\circ} \mathrm{C}$, $90^{\circ} \mathrm{C}-95^{\circ} \mathrm{C}$ berbeda nyata. Dengan demikian, suhu ekstraksi terbaik terhadap rendemen pektin adalah pada suhu $90^{\circ} \mathrm{C}$ $95^{\circ} \mathrm{C}$, dapat direkomendasikan untuk aplikasikan dalam ekstraksi pektin dari kulit buah manga harumanis.

\section{Rendemen Pektin Pada Berbagai Waktu Ekstraksi}

Ekstraksi pektin tidak hanya dipengaruhi oleh suhu, tetapi juga waktu ekstraksi (Prasetyowati dan Pesantri, 2009). Adapun suhu yang diterapkan adalah $90-95^{\circ} \mathrm{C}$ yang merupakan suhu ekstraksi terbaik dari perlakuan 
sebelumnya. Pada penelitian ini dilakukan variasi waktu ekstraksi untuk melihat waktu terbaik terhadap rendemen pektin yaitu 60 menit, 90 menit, 120 menit, 150 menit dan 210 menit. Hasil rendemen pektin yang diperoleh pada (Gambar 2) yaitu $30,77 \%, 35,64 \%, 40,17 \%, 49,13 \%$, $45,49 \%$ dan $42,82 \%$. Dari hasil yang diperoleh terlihat bahwa semakin lama waktu ekstraksi maka rendemen pektin yang dihasilkan semakin besar.

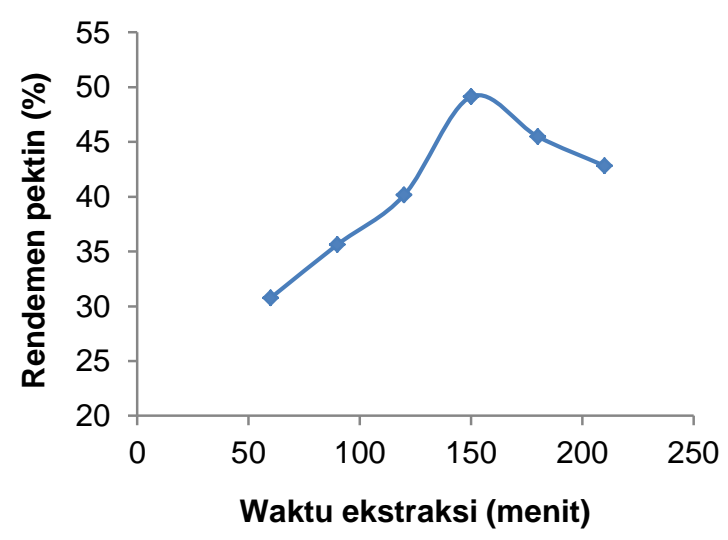

Gambar 2. Pengaruh waktu ekstraksi terhadap rendemen pektin

Menurut Nuh (2017), semakin lama ekstraksi maka jaringan tanaman akan semakin lunak sehingga protopektin (senyawa pektin yang tidak larut dalam air) yang terdapat dapat dalam jaringan tanaman akan semakin banyak terhidrolisis menjadi pektin yang larut air, sehingga rendemen yang dihasilkan semakin banyak pula. Namun pada waktu ekstraksi 210 menit, rendemen pektin yang dihasilkan menurun. Waktu ekstraksi pektin berbanding lurus kadar pektin, tetapi pada waktu yang terlalu panjang dapat menyebabkan pektin terdegradasi menjadi asam pektat, sehingga diperlukan penentuan waktu optimum (Evi et al., 2003).

Hasil analisis uji statistik pada tabel sidik ragam Anova, menggunakan taraf kepercayaan $95 \%(\alpha=0,05)$ dengan nilai signifikan 0,00 ( $\mathrm{p}$ value) $<\alpha$ dengan kata lain terdapat pengaruh waktu ekstraksi terhadap rendemen pektin yang dihasilkan, oleh karena itu dapat dilakukan analisis lanjut dengan uji Duncan untuk menentukan waktu ekstrasi terbaik pada kulit buah mangga.

Hasil uji lanjut Duncan dengan taraf kepercayaan $95 \%(\alpha=0,05)$ menunjukkan terbentuknya 6 kolom yang dihasilkan tiap kelompok pada kolom yang berbeda. Waktu ekstraksi 60, 90, 120, 210, 180, dan 150 menit saling berbeda nyata satu sama lain. Dengan demikian, waktu ekstraksi terbaik terhadap rendemen pektin yaitu diperoleh pada 150 menit dapat direkomendasikan untuk aplikasikan dalam ekstraksi pektin dari kulit buah manga harumanis.

\section{Karakteristik Pektin}

\section{A. Kadar Air}

Kadar air suatu bahan berpengaruh terhadap masa simpan bahan. Kadar air yang terlalu tinggi dapat menyebabkan mikroba mudah tumbuh (Budiyanto dan Yulianingsih, 2008). Berdasarkan hasil analisis kadar air yang diperoleh pada penelitian ini yaitu 8,2 \%. Menurut IPPA (International Pectin Producer Association) (2002), syarat kadar air pektin yang maksimum adalah tidak lebih 
dari $12 \%$, sehingga hasil kadar air pektin yang diperoleh pada penelitian ini masih dibawah syarat maksimum.

Tingginya kadar air pektin yang dihasilkan dipengaruhi oleh pengeringan yang kurang maksimal serta kondisi penyimpanannya sebelum dilakukan uji kadar air pektin (Utami, 2014). Kadar air pektin dipengaruhi oleh derajat pengeringan. Jika derajat pengeringan rendah maka yang terlihat adalah berat rendemen yang lebih besar daripada yang sebenarnya. Penyimpanan pada tempat yang lembab dan wadah yang tidak kedap udara akan menyebabkan kerentanan pektin terpapar udara luar, sehingga pektin menjadi lembab (Fitriani, 2003).

\section{B. Kadar Metoksil}

Sifat fungsional larutan pektin dan struktur serta tekstur gel pektin sangat ditentukan oleh kadar metoksil atau gugus metoksil yang terdapat didalam struktur pektin (Constenla dan Lozano, 2003). Berdasarkan hasil analisis kadar metoksil pada pektin kulit buah mangga didapatkan kadar metoksil sebesar 9,569 \% yang tergolong pektin bermetoksil tinggi. Menurut IPPA (International Pectin Producer Association) (2002) metoksil dengan kandungan sebesar < 7,12 \% tergolong pektin bermetoksil tinggi.

Hasil yang diperoleh penelitian ini tergolong dalam pektin bermetoksil tinggi, sehingga tingginya kadar metoksil dalam molekul dapat mempercepat pektin menjadi gel (Hariyati, 2006). Pemanfaatan pektin yang bermetoksil tinggi dalam suatu produk pangan seperti pudding, selai dan jelly, untuk yang bermetoksil rendah sangat sesuai untuk bahan penyalut (Silvana, 2013).

\section{Kadar Galakturonat}

Hidrolisis protopektin menjadi pektin memiliki komponen dasar berupa asam Dgalakturonat. Kadar asam galakturonat serta muatan molekul pektin juga sangat mempengaruhi sifat fungsional pektin. Nilai kadar galakturonat yang semakin tinggi akan diikuti oleh mutu pektin yang semakin tinggi (Constenla dan Lozano, 2002).

Berdasarkan hasil analisis kadar galakturonat yang diperoleh pada penelitian ini sebesar $74,155 \%$. Menurut IPPA (International Pektin Producer Association) (2002) syarat kadar galakturonat pektin yang minimal $35 \%$. Kadar galakturonat pada penelitian ini telah memenuhi standar yang ditetapkan.

Kadar galakturonat juga meningkat akibat ikatan komponen galakturonat pektin terputus dengan senyawa-senyawa lain seperti hemiselulosa. Dengan meningkatnya persentase galakturonat, sehingga kemurnian pektin yang diperoleh semakin besar dan akan mempengaruhi mutu pektin yang dihasilkan (Rasyid, 1986).

\section{Spektrum FTIR}

Identifikasi gugus fungsional senyawa pektin dianalisis dengan pektrofotometer FTIR pada panjang 
gelombang 4000-400 $\mathrm{cm}^{-1}$. Spektrum infra merah pektin (Gambar 3) menunjukkan, serapan dari gugus hidroksil $(-\mathrm{OH})$ terdapat pada bilangan gelombang $3448,72 \mathrm{~cm}^{-1}$. Pada penelitian yang dilakukan oleh Fitri (2016), spektrum pektin yang terkait dengan gugus $(-\mathrm{OH})$ terdapat pada bilangan gelombang $3412,08 \mathrm{~cm}^{-1}$. Hasil spektrum yang diperoleh diperkuat dengan pernyataan Pavia et al (2009), bahwa spektra pektin yang berkaitan dengan gugus $-\mathrm{OH}$ terletak pada bilangan gelombang $3200-3650$ $\mathrm{cm}^{-1}$.

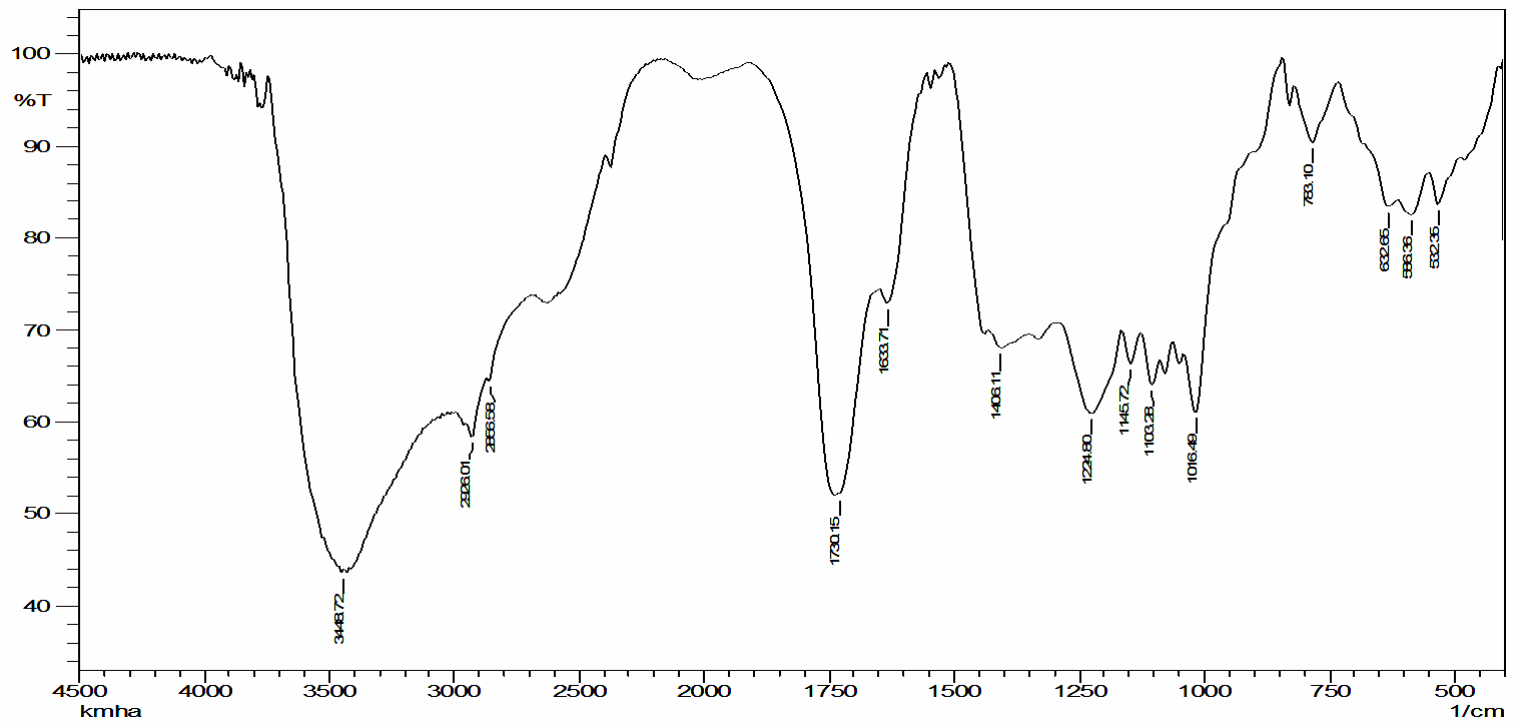

Gambar 3 Spektrum FTIR pektin kulit buah mangga harumanis (Mangifera indica L.)

Serapan pada bilangan gelombang 2926,01 $\mathrm{cm}^{-1}$ menunjukkan adanya serapan ulur $-\mathrm{CH}_{3}$. Madjaga et al. (2017) melaporkan bahwa spektra pektin yang terkait dengan gugus $\left(\mathrm{CH}_{3}\right)$ terdapat pada bilangan gelombang 2927,94 $\mathrm{cm}^{-1}$. Hasil spektrum yang diperoleh diperkuat dengan pernyataan Hadri et al. (2012), bahwa spektra pektin yang berkaitan dengan gugus $\left(-\mathrm{CH}_{3}\right)$ terletak pada bilangan gelombang $2700-3050 \mathrm{~cm}^{-1}$.

Pada daerah bilangan gelombang $1730,15 \mathrm{~cm}^{-1}$ menunjukkan adanya gugus $-\mathrm{C}=\mathrm{O}$ (karbonil). Fitria (2016) menytakan bahwa spektra gugus karbonil $(\mathrm{C}=\mathrm{O})$ terletak pada bilangan gelombang $1743,65 \mathrm{~cm}^{-1}$. Menurut Hadri et al (2012), yang menyatakan spektrum gugus karbonil $\left(\mathrm{CH}_{3}\right)$ terletak pada bilangan gelombang $1630-1850 \mathrm{~cm}^{-1}$.

Pita serapan pada bilangan gelombang 1406,11 $\mathrm{cm}^{-1}$ menunjukkan adanya ikatan -C-H. Hal ini sesuai dengan penelitian Sufy (2015), menyatakan bahwa ikatan -C-H terletak pada bilangan gelombang 1421,60 cm-1. Menurut Pavia et al. (2009), bilangan gelombang ikatan -C-H terletak pada kisaran bilangan gelombang $1450-1375 \mathrm{~cm}^{-1}$.

Pita serapan pada bilangan gelombang $1145,72 \mathrm{~cm}^{-1}$, menunjukkan ikatan dari eter (R-O-R) dari molekul pektin. Pada penelitian Sufy (2015) pada bilangan gelombang 1146,73 $\mathrm{cm}^{-1}$. 
Menurut Pavia et al. (2009) bahwa ikatan eter (R-O-R) berada pada kisaran spektrum $1050-1260 \mathrm{~cm}^{-1}$.

\section{KESIMPULAN}

Suhu ekstraksi pektin terbaik dari kulit buah manga terdapat pada suhu 90$95^{\circ} \mathrm{C}$ dengan rendemen $40,19 \%$ dan waktu ekstraksi pektin terbaik adalah 150 menit dengan rendemen pektin 49,13\%. Karakteristik pektin kulit buah mangga, antara lain kadar air 8,2\%, kadar metoksil 9,57\%, kadar galakturonat $74,16 \%$. Pada spektrum FTIR pektin, terdapat gugus $-\mathrm{OH}$ pada bilangan gelombang $3448,72 \mathrm{~cm}^{-1}$, serapan ulur $-\mathrm{CH}_{3}$ pada bilangan gelombang 2926,01 $\mathrm{cm}^{-1}, \quad-\mathrm{C}=\mathrm{O}$ pada bilangan gelombang $1730,15 \mathrm{~cm}^{-1}$, tekuk $\mathrm{C}-\mathrm{H}$ pada bilangan gelombang 1145,72 $\mathrm{cm}^{-1}$, dan ikatan R-O-R terletak pada bilangan gelombang $1406,11 \mathrm{~cm}^{-1}$.

\section{DAFTAR PUSTAKA}

Akhmalludin dan Kurniawan, A. 2009. Pembuatan Pektin dari Kulit Coklat dengan Cara Ekstraksi. (diunduh di http://eprints.undip.ac.id/3302/1/ma kalh_ku_Akmaludin_pdf.pdf., tanggal 5 September 2018)

Arviani. 2009. Studi Perbandingan Metode Ekstraksi Pektin dari Kulit Jeruk (Citrus Sp). Skripsi. Palu: Jurusan Kimia Fakultas MIPA, Universitas Tadulako.

Budiyanto, A dan Yulianingsih. 2008. Pengaruh Suhu dan Waktu Ekstraksi Terhadap Karakter Pektin dari Asam Jeruk Siam (Citrus nobilis L). Bogor: Balai Besar Penelitian dan Pengembangan Pasca Panen Pertanian.
Constenla, D. dan J. E. Lozano. 2003. Kinetic Model of Pectin Demethylation. Latin American Applied Research, 33 : 91-96.

Evi, Z., N, N., Yuli, Rusdiansyah. 2013. Pengaruh Suhu dan Waktu Terhadap Hasil Ekstraksi Pektin dari Kulit Buah Nanas. Simposium Nasional RAPI XII. FT UMS.

Febriyanti, Y., Razak, A. R., \& Sumarni, N. K. 2018. Ekstraksi dan Karakterisasi Pektin dari Kulit Buah Kluwih (Artocarpus camansi Blanco). KOVALEN, 4(1): 60-73.

Fitri, A. 2016. Pektin Dari Kulit Buah Kakao (Theobroma cacao L.) Sebagai Edible Coating Buah Tomat. Skripsi. Kendari: Fakultas Matematika dan Ilmu Pengetahuan Alam. Universitas Halu Oleo.

Fitriani, V. 2003. Ekstraksi dan karakterisasi pektin dari kulit jeruk lemon (Citrus medica var Lemon). Skripsi. Bogor: Fakultas Teknologi Pertanian IPB.

Hadri, M. El., Achahbar., Khamkhami, J., El., Khelifa, B., Faivre, V., Truong Cong, T., Bougrioua, F., Bresson, S. 2012. Raman Spectroscopy investigation of mono- and diacylpolyoxyethylene glycol. France: Laboratoire De Phyque The Systemes Complexes, UPJV. Amiens.

Hariyati, M. N. 2006. Ekstraksi dan Karakteristik Pektin dari Limbah Proses Pengelolahan Jeruk Pontianak (Citrus nobilis var mierocarpa). Skripsi. Bogor: Fakultas Teknologi Pertanian Institut Pertanian Bogor. 
Injilaudin, S.A, Lutfi, M., Nugroho, A. W. 2015. Pengaruh suhu dan waktu pada proses ekstraksi pektin dari kulit buah nangka (Artocarpus heterophyllus). Jurnal Keteknikan Pertanian Tropis dan Biosistem, 3(3).

IPPA (International Pectin Produres Association. 2002. What is Pectin. http://www.ippa.info/history of pektin. htm, diakses tanggal 1 September 2018.

Kertesz, Z.I. 1951. The pection subtances. New York: Interscience Pub.

Madjaga, B.H., Nurhaeni., \& Ruslan. 2017. Optimalisasi ekstraksi pektin dari kulit buah sukun (Artocarpus Altillis). KOVALEN, 3(2): 158-162.

Margani, A. D., Wignyanto, L. R. Nur. 2012. Pelarut dan Lama Ekstraksi Terbaik Dalam pembuatan Pektin dari Limbah Kulit Buah Nangka (Jerami dan Kulit). Laporan Penelitian. Malang: Fakultas Teknologi Pertanian. Universitas Brawijaya.

Nuh, M. 2017. Pengaruh Suhu dan Lama Ekstraksi Terhadap Mutu Pektin Kulit Pisang Kepok. WAHANA INOVASI 6 (2): 144-148.

Nurviani, N., Bahri, S., \& Sumarni, N. K. 2014. Ekstraksi dan karakterisasi pektin kulit buah pepaya (Carica papaya l.) Varietas cibinong, jingo dan semangka. Natural Science : Journal of Science and Technology 3(3).

O'Neil, MA., Ishii, T., Albersheim, P., Darvill, $\quad$ AG. 2014. Rhamnogalacturonan II : Structure and function of borate cross-linked cell wall pectin polysaccharide. Annu. Rev. Plant Biol. 55: 109-139.

Pavia, D., Lampmam, G.M., Kriz, G.S., Vyvyan J.R. 2009. Introduction to spectroscopy edition IV. Washington:
Departement of Chemistry. Western Washington University.

Prasetyowati, K. P. S dan P, Healthy. 2009. Ekstraksi Pektin dari Kulit Mangga. Jurnal Teknik Kimia 4 (16) : 42-49.

Rachmawan, S. 1997. Manual of Analysis of fruit and Vegetables Product. New Delhi: McGraw Hill.

Rasyid, H. A. 1986. Ekstraksi Pektin dari Pulp Kopi. Skripsi. Bogor: Fakultas Teknologi Pertanian, Institut Pertanian Bogor.

Silvana, P. 2013. Penggunaan Berbagai Jenis Asam Dalam Ekstraksi Pektin Kulit Buah Kakao Dari Beberapa Varietas Buah Kakao (Theobroma cacao, L). Skripsi. Palu: Jurusan Kimia. Fakultas Matematika dan IImu Pengetahuan Alam. Universitas Tadulako.

Sufy, Q. 2015. Pengaruh variasi perlakuan bahan baku dan konsentrasi asam terhadap ekstraksi dan karakteristik pektin dari limbah kulit pisang kapok kuning (Musa balbisiani BBB). Skripsi. Jakarta: Program Studi Farmasi Fakultas Kedokteran dan IImu Kesehatan, UIN Syarif Hidayatullah.

Sutono, 2008. Budidaya Tanaman Mangga (Mangifera indica). Bogor: Balai Penelitian Tanah.

Towle, G.A dan O, Christensen. 1997. Pectin. Di dalam R.L Whistler (ed.) Industrial Gum. New York: Academic Press,.

Ulfia. 2016. Modul Pelatihan Pembuatan Jam (Selai). Bali: Tropical Plant Curriculum Project, Pusat Studi Ketahanan Pangan, Universitas Udayana. 
Utami, Rizki. 2014. Ekstraksi dari Kulit Kakao dengan Pelarut Ammonium Oksalat. Skripsi. Banda Aceh: Fakultas Pertanian, Universitas Syiah Kuala.

Willats, W. G., Knox, J. P., \& Mikkelsen, J. D. 2006. Pectin : now insight into an old polymer are strating to gel. Trend in Food Science \& Technology, 17(13) : 97-104. 